\title{
PENGARUH BUDAYA ORGANISASI, MOTIVASI DAN KEPEMIMPINAN TERHADAP KINERJA PEGAWAI PADA DINAS KOMUNIKASI DAN INFORMATIKA KABUPATEN KOTAWARINGIN TIMUR
}

\section{THE INFLUENCE OF ORGANIZATIONAL CULTURE, MOTIVATION AND LEADERSHIP TOWARDS PERFORMANCE} OF EMPLOYEES IN THE COMMUNICATION AND INFORMATICS SERVICES OF EAST KOTAWARINGIN DISTRICT

\section{Syamsuril* \\ Marina Gati Endah Mumpuni2 \\ Indah Nur Oktavia ${ }^{3}$}

\author{
* FISIP Universitas Palangka Raya. \\ 2 Magister Administrasi Publik, Universitas \\ Terbuka, Indonesia. \\ 3 FISIP Universitas Palangka Raya.
}

\author{
*email: \\ *I syam_najwa@yahoo.co.id. \\ *2 marinagati@ymail.com \\ *3 Indahnuroktavia0509@gmail.com
}

\begin{abstract}
Abstrak
Penelitian ini bertujuan untuk mengetahui dan menganalisis pengaruh budaya organisasi, motivasi dan kepemimpinan terhadap kinerja pegawai, baik secara parsial maupun simultan. Penelitian ini merupakan jenis penelitian kuantitatif eksplanatory dengan pengambilan data secara langsung dari responden yang berjumlah 24 pegawai dengan teknik sampling sensus menggunakan kuesioner. $\mathrm{Hal}$ ini berarti bahwa seluruh responden pada unit analisis dijadikan sebagai sampel penelitian. Dari hasil penelitian dengan pengukuran variabel menggunakan Skala Likert dengan Teknik Analisis Regresi Berganda setelah melalui uji instrumen (uji validitas dan reliabilitas), uji asumsi klasik dan uji hipotesis menggunakan SPSS versi 25.0, menunjukkan bahwa secara parsial maupun simultan, variabel budaya organisasi, motivasi dan kepemimpinan berpengaruh secara positif dan signifikan terhadap kinerja pegawai pada Dinas Komunikasi dan Informatika Kabupaten Kotawaringin Timur. Dari studi ini juga dapat disarankan bahwa melalui peningkatan pemahaman akan budaya organisasi, motivasi kerja dan kepemimpinan yang baik akan berdampak nyata dalam peningkatan kinerja pegawai dan sangat menentukan keberhasilan pencapaian tujuan organisasi ke depan.
\end{abstract}

\section{Kata Kunci: \\ Budaya Organisasi, \\ Motivasi, \\ Kepemimpinan, \\ Kinerja Pegawai.}

Keywords:

Organizational culture,

Motivation,

Leadership,

Employee Performance.

\begin{abstract}
This study aims to determine and analyze the influence of organizational culture, motivation and leadership on employee performance, both partially and simultaneously. This research is an explanatory quantitative research by taking data directly from respondents, amounting to 24 employees with census sampling technique using a questionnaire. This means that all respondents in the unit of analysis are used as research samples. From the results of the study by measuring variables using a Likert Scale with Multiple Regression Analysis Techniques after passing the instrument test (validity and reliability test), the classic assumption test and hypothesis testing using SPSS version 25.0, showed that partially or simultaneously, variables of organizational culture, motivation and leadership a positive and significant effect on employee performance at the Office of Communication and Information of East Kotawaringin Regency. From this study it can also be suggested that through increased understanding of organizational culture, work motivation and good leadership will have a real impact in improving employee performance and will determine the success of achieving organizational goals going forward.
\end{abstract}

(C) yearThe Authors. Published by Institute for Research and Community Services Universitas Muhammadiyah Palangkaraya. This is Open Access article under the CC-BY-SA License (http://creativecommons.org/licenses/bysa/4.0/). DOI: https://doi.org/10.33084/anterior.v18i2.456.

\section{Pendahuluan}

Dalam rangka meningkatkan kinerja pegawai yang berkualitas dan professional salah satu faktor yang cocok untuk diterapkan dalam lingkungan kerja ialah budaya organisasi. Budaya organisasi dapat membantu kinerja pegawai, karena menciptakan suatu tingkat motivasi yang luar biasa bagi pegawai untuk memberikan kemampuan terbaiknya dalam memanfaatkan kesempatan yang diberikan oleh organisasinya. untuk menerapkan budaya organisasi yang cocok pada sebuah organisasi, maka diperlukan adanya dukungan dan partisipasi dari semua anggota yang ada dalam lingkup organisasi tersebut (Azizy, 2007).

Selain faktor budaya organisasi, salah satu faktor dominan yang mempengaruhi kinerja organisasi adalah motivasi kerja (Robbins, 2007). 
Memotivasi organisasi merupakan kegiatan kepemimpinan dalam mengarahkan pegawai dan organisasi agar mau bekerja secara berhasil, sehingga keinginan para pegawai dan tujuan organisasi sekaligus tercapai. Berdasarkan tujuan yang ingin dicapai, manusia akan termotivasi oleh kebutuhan yang dimilikinya termasuk di dalam fungsi ini. Motivasi pada suatu organisasi bertujuan untuk mendorong semangat kerja para pegawai agar mau bekerja keras dengan memberikan semua kemampuan dan ketrampilan demi terwujudnya suatu organisasi. Pimpinan yang mengarahkan melalui motivasi akan menciptakan kondisi dimana pegawai merasa mendapat inspirasi untuk bekerja keras.

Kepemimpinan juga mempengaruhi kinerja suatu organisasi pemerintahan, kesuksesan atau kegagalan dalam pelaksanaan tugas dan penyelenggaraan pemerintahan, dipengaruhi oleh kepemimpinan. Melalui kepemimpinan dan didukung oleh kapasitas organisasi pemerintahan yang memadai, maka penyelenggaraan tata pemerintahan yang baik (Good Governance) akan terwujud, sebaliknya kelemahan kepemimpinan merupakan salah satu sebab keruntuhan kinerja birokrasi di Indonesia (Tatulus, dkk, 20I5). Lebih lanjut Tatulus, dkk (2015) mengemukakan bahwa kepemimpinan (leadership) dapat dikatakan sebagai cara dari seorang pemimpin (leader) dalam mengarahkan, mendorong dan mengatur seluruh unsur-unsur di dalam kelompok atau organisasinya untuk mencapai suatu tujuan organisasi yang diinginkan sehingga menghasilkan kinerja pegawai yang maksimal. Dengan meningkatnya kinerja pegawai berarti tercapainya hasil kerja seseorang atau pegawai dalam mewujudkan tujuan organisasi.

Penilaian kinerja terhadap pegawai biasanya didasarkan pada job description yang telah disusun oleh organisasi. Dengan demikian, baik buruknya kinerja pegawai dilihat dari kemampuannya dalam melaksanakan tugas-tugas sesuai dengan pekerjaan yang telah menjadi tanggung jawabnya. Sedangkan kinerja sendiri adalah tingkat pencapaian hasil atas pelaksanaan tugas tertentu. Seperti yang dikemukan Rue \& Bryan dalam Tjandra (2005) kinerja didefinisikan sebagai "tingkat pencapaian hasil serta merupakan tingkat pencapaian tujuan organisasi secara berkesinambungan". Suatu organisasi baik pemerintah maupun swasta dalam mencapai tujuan yang ditetapkan harus melalui

\section{Kajian Pustaka \\ Budaya Organisasi}

Schein dalam (Muchlas, 2005) mengatakan pengertian budaya organisasi sebagai "sebuah corak dari asumsi-asumsi dasar, yang ditemukan atau dikembangkan oleh sebuah kelompok tertentu untuk belajar mengatasi problem-problem sarana dalam bentuk organisasi yang digerakkan oleh sekelompok orang yang berperan aktif sebagai pelaku dalam mencapai tujuan organisasi yang bersangkutan. Tercapainya tujuan organisasi hanya dimungkinkan karena upaya para individu yang terdapat pada organisasi tersebut. Dengan kata lain, kinerja individu berhubungan sejalan dengan kinerja organisasi. Selain kinerja individual yang harus sangat diperhatikan dalam suatu organisasi, hal lain yang menjadi salah satu penentu kinerja dari suatu organisasi tersebut adalah kepemimpinan dari organisasi tersebut. Pengaruh kepemimpinan merupakan norma perilaku yang digunakan oleh seseorang pada saat orang tersebut mencoba mempengaruhi perilaku orang lain. Kepemimpinan akan mengarahkan budaya organisasi yang kuat dan membangkitkan motivasi kerja para pegawai yang tinggi dalam bekerja sehingga berdampak terhadap kinerja pegawai maupun organisasi.

Beberapa penelitian terdahulu tentang pengaruh budaya organisasi, motivasi, kepemimpinan terhadap kinerja pegawai yang dilakukan oleh Marimin (20II), Tapoona (20I4), Shati dan Dewi (20I4), Mappamiring (20I5), Brury (2016), Lingga dan Siregar (2016), Wijayanti (20।6), Widodo (20I7), Tewal, dkk (20I7), Rahayuningsih (2018) menyimpulkan bahwa budaya organisasi, motivasi dan kepemimpinan berpengaruh positif dan signifikan terhadap kinerja pegawai. Sementara penelitian terdahulu yang dilakukan oleh Parmin (2015) menyimpulkan bahwa kepemimpinan dan motivasi kerja tidak berpengaruh terhadap kinerja, sedangkan budaya organisasi berpengaruh positif dan signifikan terhadap kinerja pegawai. Demikian juga dengan penelitian terdahulu yang dilakukan oleh Ariyawan, dkk (2018) yang menyimpulkan bahwa kepemimpinan dan budaya organisasi berpengaruh signifikan terhadap peningkatan kinerja pegawai. Studi terdahulu yang dilakukan oleh Juanti (2017), Habba (2017) menunjukkan bahwa kepemimpinan dan budaya organisasi tidak berpengaruh terhadap peningkatan kinerja pegawai, sedangkan motivasi kerja berpengaruh terhadap kinerja pegawai. Dari beberapa penelitian tersebut dapat ditarik suatu kesimpulan bahwa pengaruh budaya organisasi, motivasi dan kepemimpinan terhadap kinerja pegawai mempunyai dampak yang berbeda-beda.

kelompok dari adaptasi eksternal dan integrasi internal, yang telah bekerja dengan baik". Mangkunegara (2005) mendefinisikan budaya organisasi adalah "seperangkat asumsi atau sistem keyakinan, nilai-nilai dan norma yang dikembangkan dalam organisasi yang dijadikan pedoman tingkah laku bagi anggota-anggotanya untuk mengatasi masalah adaptasi eksternal dan integrasi internal". 
Budaya organisasi itu sendiri memiliki karakteristik yang akan tertanam di lingkungan internal sebuah organisasi. Karakteristik ini yang nantinya akan tertanam pada masing-masing anggota organisasi. Karakteristik yang sudah tertanam pada masingmasing anggota organisasi akan menciptakan ciri khas bagi organisasi tersebut. Untuk itu perlu ditanamkan karakter yang seragam di dalam sebuah organisasi.

\section{Motivasi}

Robbins (2007) mendefinisikan motivasi adalah "kesediaan individu untuk mengeluarkan upaya yang tinggi untuk mencapai tujuan organisasi". Motivasi merupakan salah satu faktor penting dalam mendorong seorang karyawan untuk bekerja. Tanpa adanya motivasi dalam diri seseorang, maka dapat dipastikan bahwa orang itu tidak akan bergerak sedikitpun dari tempatnya berada. Menurut Hasibuan (2007), "motivasi adalah pemberian daya penggerak yang menciptakan kegairahan kerja seseorang agar mereka mau bekerja sama, bekerja efektif dan terintegrasi dengan segala daya upayanya untuk mencapai kepuasan".

\section{Kepemimpinan}

Wirjana dan Supardo (1999), kepemimpinan didefinisikan "sebagai suatu proses yang kompleks dimana seseorang mempengaruhi orang lain untuk mencapai suatu misi, tugas, atau sasaran, dan mengarahkan organisasi dengan cara yang membuatnya lebih kohesif dan lebih masuk akal". Hasibuan (2007) menyatakan kepemimpinan adalah "cara seseorang mempengaruhi perilaku bawahan, agar mau bekerjasama dan bekerja secara produktif untuk mencapai tujuan organisasi”. Bukan hanya menentukan sasaran-sasaran dalam mencapai tujuan organisasi, seorang pemimpin juga dituntut untuk berupaya membantu bawahan dalam menyelesaikan tugas mereka dengan baik, berupa pengawasan, mengatur koordinasi dan juga memberi motivasi untuk membangkitkan semangat kerja pegawai.

Kinerja

Kusnadi (2003) menyatakan bahwa kinerja adalah "setiap gerakan, perbuatan, pelaksanaan, kegiatan atau tindakan yang diarahkan untuk mencapai tujuan atau target tertentu". Dengan demikian, kinerja seorang pegawai dapat diukur dari hasil kerja, hasil tugas, atau hasil kegiatan dalam kurun waktu tertentu (Notoatmodjo, 2009). Kinerja merupakan suatu fungsi dari motivasi dan kemampuan seorang karyawan. Kinerja

\section{Hasil dan Diskusi Hasil penelitian}

Analisis regresi berganda (multiple regression) dilakukan untuk menguji hipotesis penelitian untuk mengetahui pengaruh antara (performance) dapat juga diartikan sebagai hasil kerja atau prestasi kerja. Kinerja adalah perilaku nyata yang ditampilkan setiap orang sebagai prestasi kerja yang dihasilkan oleh karyawan sesuai dengan perannya dalam perusahaan. Kinerja karyawan sangat penting dalam upaya perusahaan untuk mencapai tujuannya. Kinerja mempunyai makna yang lebih luas, bukan hanya menyatakan sebagai hasil kerja, tetapi juga bagaimana proses kerja berlangsung. Faktor penentu kinerja dalam kerangka yang lebih luas, dinyatakan bahwa terdapat tiga faktor penentu kinerja, yaitu kemampuan, motivasi dan kesempatan. Kesempatan merupakan faktor yang bukan termasuk dalam internal bawahan, tetapi lebih tergantung pada kebijakan yang ditetapkan oleh pimpinan atau pemberi kerja (Robbins, 2007).

\section{Metodologi}

Jenis penelitian yang dilakukan dalam penelitian ini adalah penelitan penjelasan (explanatory research) dengan pendekatan kuantitatif menggunakan kuesioner sebagai alat pengumpulan data primer. Penarikan sampel dalam penelitian ini adalah dengan menggunakan teknik sampel total atau sampling jenuh, yakni semua populasi dijadikan sebagai sampel sebanyak 24 orang pegawai. Untuk melakukan analisis terhadap hasil hasil uji statistik dan mengetahui nilai mean, maximum, minimum dan standar deviasi dari sampel yang diteliti, peneliti menggunakan analisis statistik deskriptif, yakni menggambarkan data yang telah terkumpul sebagaimana adanya tanpa bermaksud membuat kesimpulan yang berlaku untuk umum atau generalisasi. Kemudian untuk menganalisis hipotesis yang diajukan menggunakan teknik analisis regresi berganda (multiple regresion) dengan Software IBM SPSS Version 25.0. Model persamaan regresi pada studi ini yaitu:

$$
Y=\beta_{o}+\beta_{1} X_{1}+\beta_{2} X_{2}+\beta_{3} X_{3}+\varepsilon
$$

Dimana, $Y$ adalah variabel kinerja pegawai; $X I$ adalah variabel budaya organisasi; $X 2$ adalah variabel motivasi; $\times 3$ adalah variabel kepemimpinan; $\beta_{0}$ adalah konstanta; $\beta_{1}, \beta_{2}$ adalah koefisien regresi; dan $\varepsilon$ adalah kesalahan residu (error term). Analisis data yang dilakukan adalah uji asumsi klasik (uji normalitas, multikolinearitas, dan heterokedastisitas) dan uji regresi berganda untuk pengujian hipotesis dengan Uji Parsial, Uji Simultan dan Uji Determinasi (Gunawan, 20I7).

variabel bebas (independent) terhadap variabel terikat (dependent). Variabel bebas yang terdapat pada studi yang dilakukan terdiri dari variabel budaya organisasi, motivasi, dan kepemimpinan, sedangkan variabel terikat adalah kinerja pegawai 


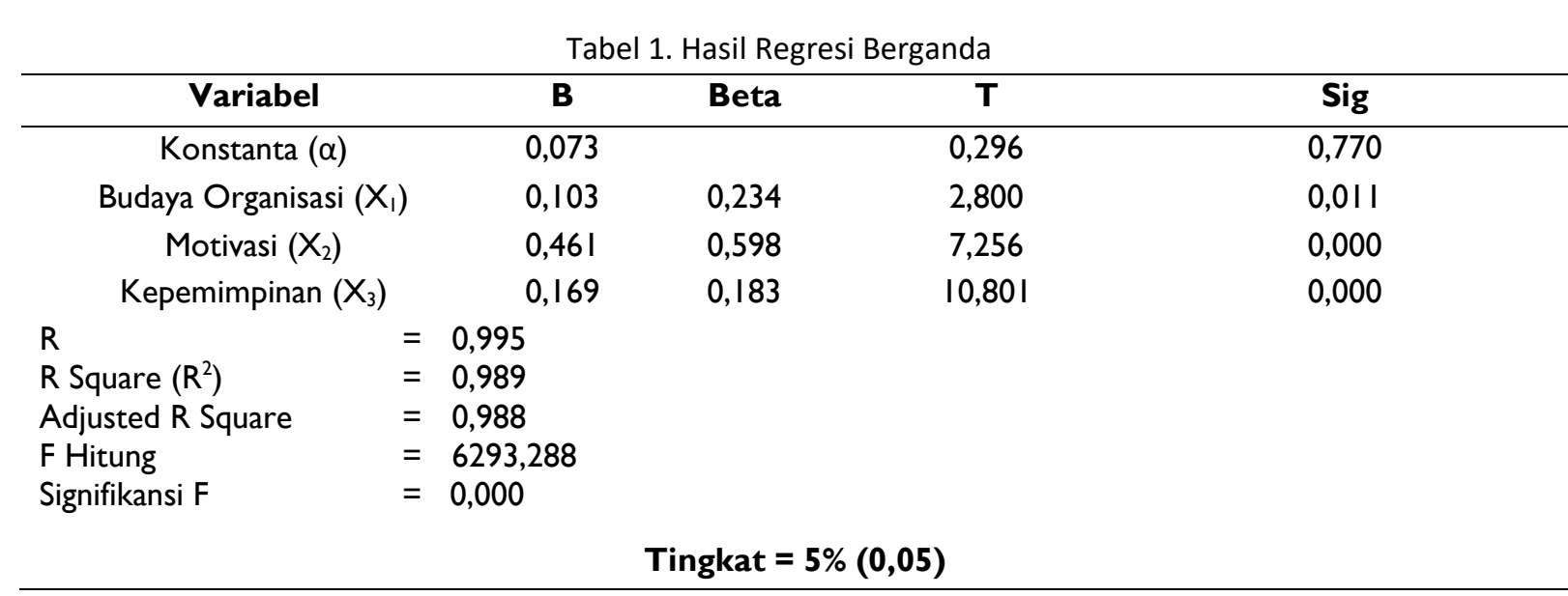

Sumber: Data Primer Diolah (2019)

Uji Asumsi Klasik

\section{Hasil Uji Normalitas}

Uji normalitas bertujuan untuk menguji apakah dalam model regresi, variabel pengganggu atau residual memiliki distribusi normal. Uji regresi mengasumsikan bahwa nilai residual mengikuti distribusi normal. Berikut hasil analisis uji normalitas masing-masing variabel budaya organisasi, motivasi, kepemimpinan dan kinerja pegawai seperti ditampilkan pada grafik seperti pada Gambar I, Gambar 2, Gambar 3 serta Gambar 4.

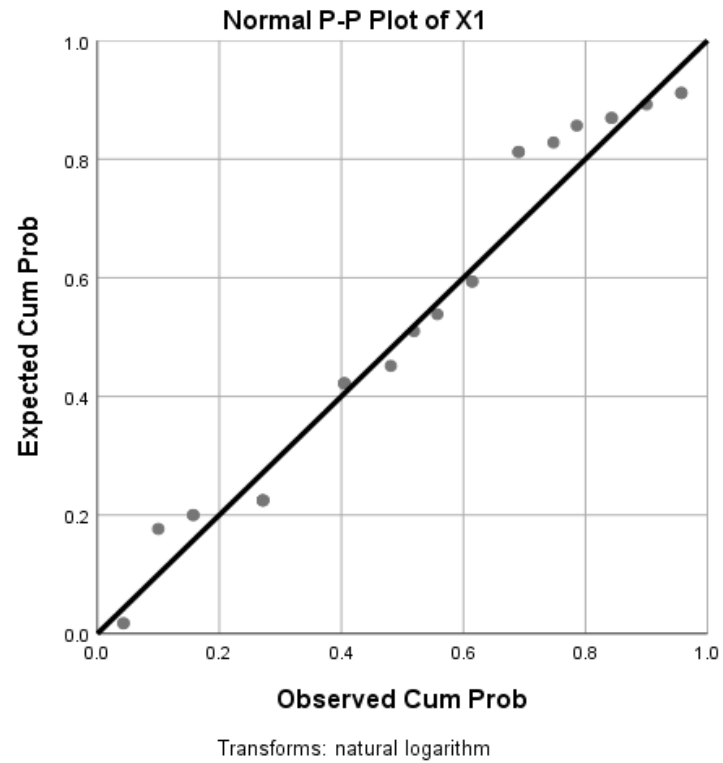

Gambar I. Kurva Normal P-P Plot Variabel Budaya Organiasi Sumber: Data Primer Diolah (2019)

Berdasarkan Gambar I dapat di lihat bahwa penyebaran titik-titik variabel budaya organisasi seluruhnya berada di sekitar garis lurus dan tidak melebar terlalu jauh sehingga diasumsikan tidak terjadi gejala normalitas. 


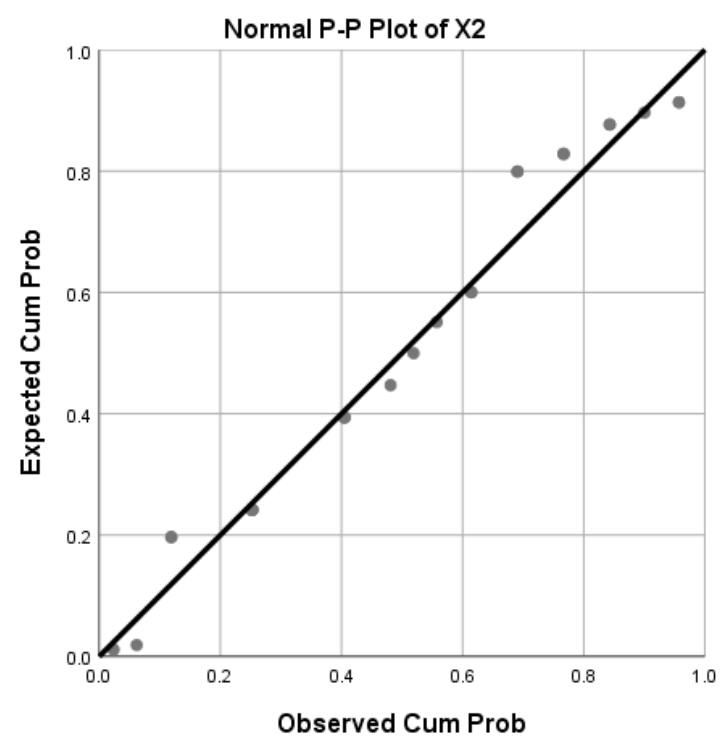

Transforms: natural logarithm

Gambar 2. Kurva Normal P-P Plot Variabel Motivasi

Sumber: Data Primer Diolah (2019)

Berdasarkan Gambar 2 diatas, dapat di lihat bahwa penyebaran titik-titik variabel motivasi seluruhnya berada di sekitar garis lurus dan tidak melebar terlalu jauh sehingga diasumsikan tidak terjadi gejala normalitas.

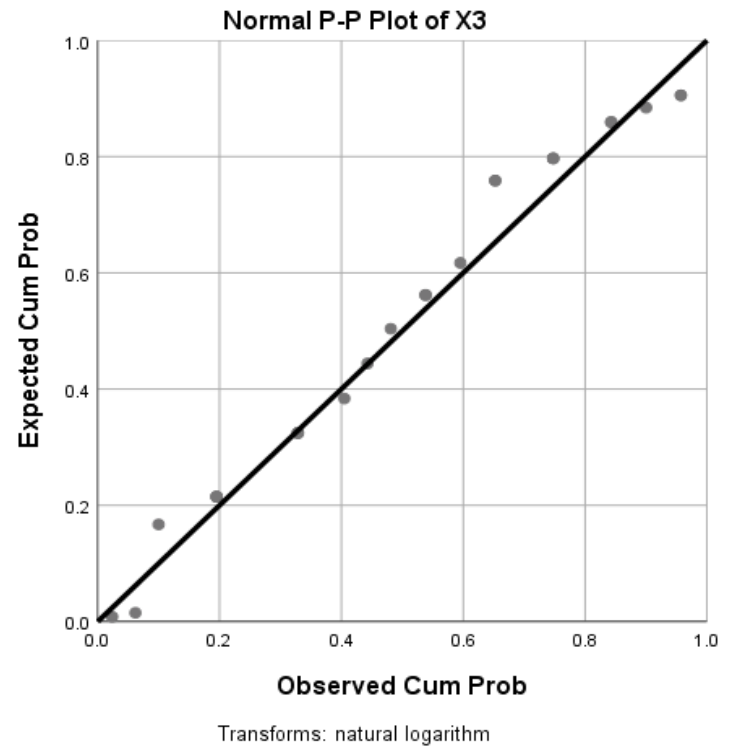

Gambar 3. Kurva Normal P-P Plot Variabel Kepemimpinan Sumber: Data Primer Diolah (2019)

Berdasarkan Gambar 3 diatas, dapat di lihat bahwa penyebaran titik-titik variabel kepemimpinan seluruhnya berada di sekitar garis lurus dan tidak melebar terlalu jauh sehingga diasumsikan tidak terjadi gejala normalitas. 


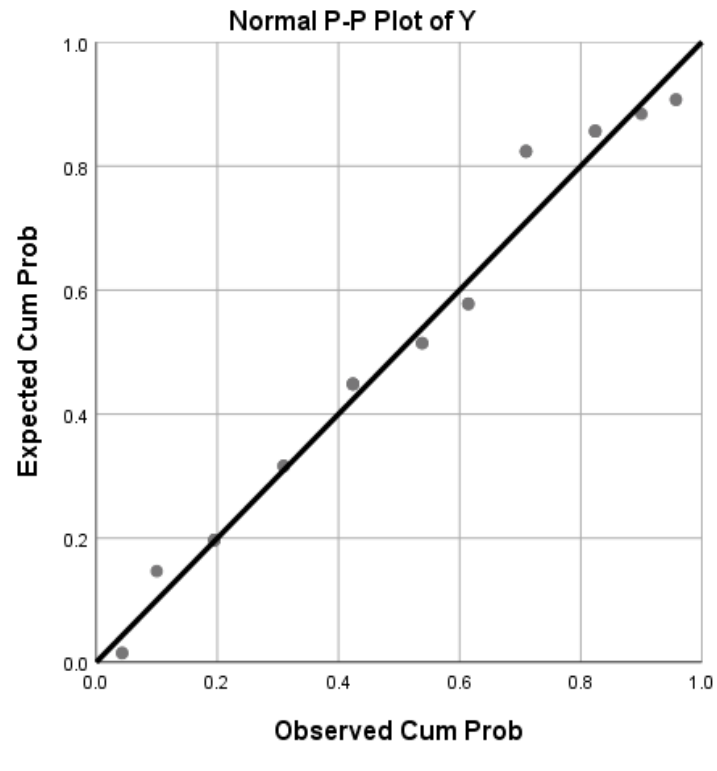

Transforms: natural logarithm

\section{Gambar 4. Kurva Normal P-P Plot Variabel Kinerja Pegawai} Sumber: Data Primer Diolah (2019)

Berdasarkan Gambar 4 di atas, dapat di lihat bahwa penyebaran titik-titik variabel kinerja pegawai seluruhnya berada di sekitar garis lurus dan tidak melebar terlalu jauh sehingga diasumsikan tidak terjadi gejala normalitas. Secara umum dapat disimpulkan bahwa variabel budaya organisasi, motivasi, kepemimpinan dan kinerja pegawai seluruhnya telah memenuhi uji normalitas sehingga dapat untuk dilakukan analisis selanjutnya.

\section{Hasil Uji Multikolinieritas}

Uji multikolianeritas bertujuan menguji apakah model regresi ditemukan adanya kolerasi antar variabel bebas (independen). Model regresi yang baik seharusnya tidak terjadi korelasi antar variabel bebas. Dalam penelitian ini, untuk mendeteksi ada atau tidaknya multikolianeritas di dalam model regresi digunakan matrik korelasi variabel-variabel bebas dan melihat nilai tolerance dari Variance Inflation Factor (VIF). Ketentuan tidak adanya problem multikolianeritas adalah nilai tolerance < 10 atau sama dengan nilai VIF > 10 (Ghozali, 2006). Hasil uji multikolinieritas semua model penelitian dijelaskan sebagai berikut. Hasil output data didapatkan bahwa masing-masing variabel bebas (budaya organisasi, motivasi, dan kepemimpinan) memiliki nilai VIF adalah (I,757, 5,218 , dan 8,454) < 10. Hal ini berarti tidak terjadi gejala multikolonieritas pada model regresi sehingga dapat disimpulkan bahwa uji multikolonieritas terpenuhi.

Tabel. 2. Hasil Uji Multikolonieritas

\begin{tabular}{|l|l|c|c|}
\hline \multicolumn{2}{|c|}{ Model } & \multicolumn{2}{c|}{ Collinearity Statistics } \\
\cline { 3 - 4 } & & Tolerance & VIF \\
\hline \multirow{2}{*}{ I. } & (Constant) & & \\
\cline { 2 - 4 } & Budaya Organisasi & 0,008 & 1,757 \\
\cline { 2 - 4 } & Motivasi & 0,008 & 5,218 \\
\cline { 2 - 4 } & Kepemimpinan & 0,183 & 8,454 \\
\hline
\end{tabular}

Sumber: Data Primer Diolah (2019)

Hasil uji multikolinieritas dari seluruh variabel penelitian yang terdiri dari variabel budaya organisasi, motivasi, dan kepemimpinan seluruhnya mempunyai nilai VIF $(1,757,5,218$, dan 8,454) < 10 . $\mathrm{Hal}$ ini berarti bahwa model regresi yang digunakan 
tidak terjadi gejala multikolonieritas, sehingga uji multikolonieritas terpenuhi.

3. Hasil Uji Heteroskedastisitas

Uji heteroskedastisitas bertujuan menguji apakah dalam model regresi terjadi ketidaksamaan variance dari residual satu pengamatan ke pengamatan yang lain. Jika variance dari residual satu pengamatan ke pengamatan lain tetap, maka disebut homoskedastisitas dan jika berbeda disebut heteroskedastisitas. Model regresi yang baik adalah yang homoskedastisitas atau tidak terjadi heteroskedastisitas (Ghozali, 2006). Dalam penelitian ini untuk menguji apakah dalam model regresi terjadi heteroskedastisitas atau tidak, penelitian ini menggunakan grafik scatterplot antara nilai prediksi variabel terikat (dependen) yaitu ZPRED dengan residualnya SRESID (Ghozali, 2006), yaitu scatterplot dari variabel budaya organisasi, motivasi, dan kepemimpinan.

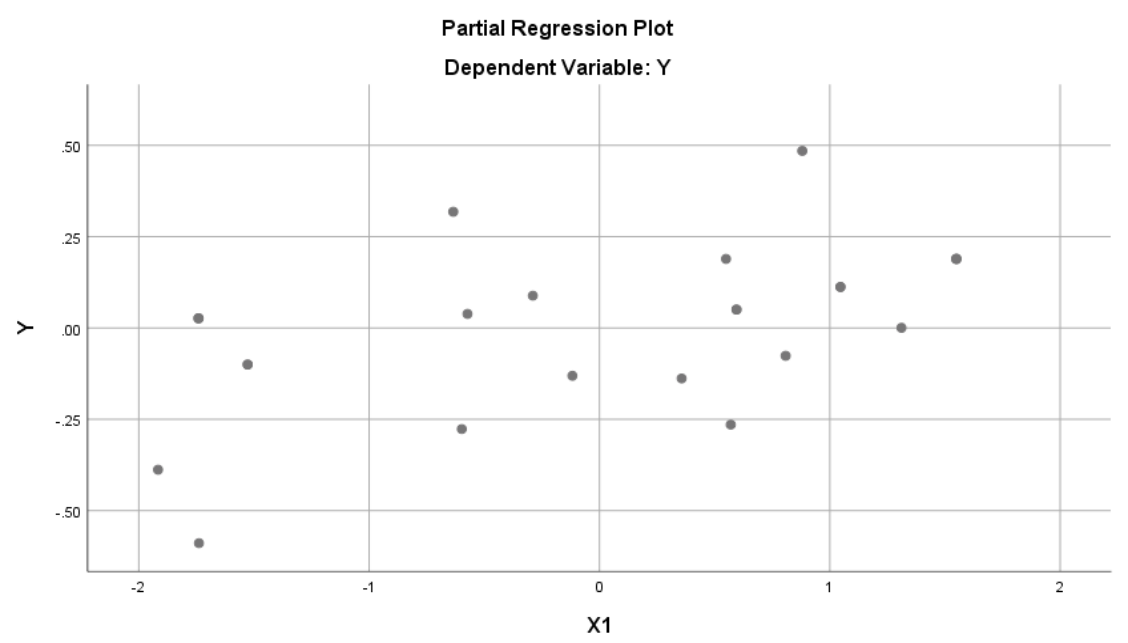

Gambar 5. Data Output Uji Heteroskedastisitas Variabel Budaya Organisasi Sumber: Data Primer Diolah (2019)

Berdasarkan Gambar 5 di atas, dapat diketahui bahwa tidak terjadi heteroskedastisitas pada variabel budaya organisasi terhadap kinerja pegawai, sebab tidak ada pola yang jelas serta titik- titik menyebar di atas dan di bawah angka 0 pada sumbu $Y$ sehingga dapat dikatakan uji heteroskedastisitas terpenuhi.

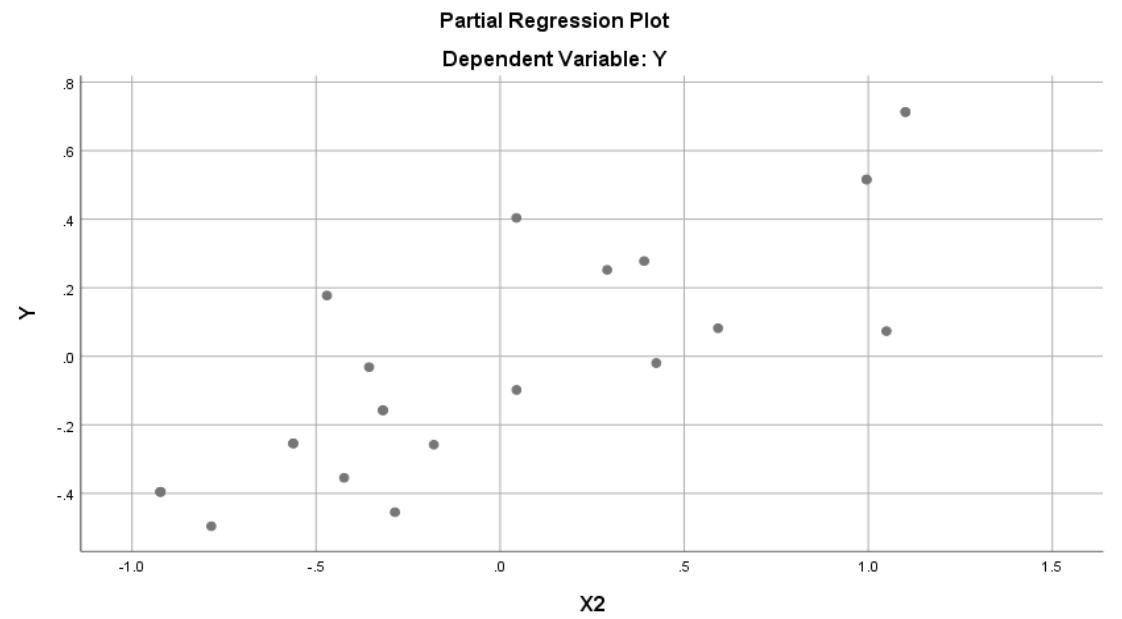

Gambar 6. Data Output Uji Heteroskedastisitas Variabel Motivasi

Sumber: Data Primer Diolah (2019)

Berdasarkan Gambar 6 di atas, dapat diketahui bahwa tidak terjadi heteroskedastisitas pada variabel motivasi terhadap kinerja pegawai, sebab tidak ada pola yang jelas serta titik-titik menyebar di atas dan di bawah angka 0 pada sumbu $Y$ sehingga dapat dikatakan uji heteroskedastisitas terpenuhi. 


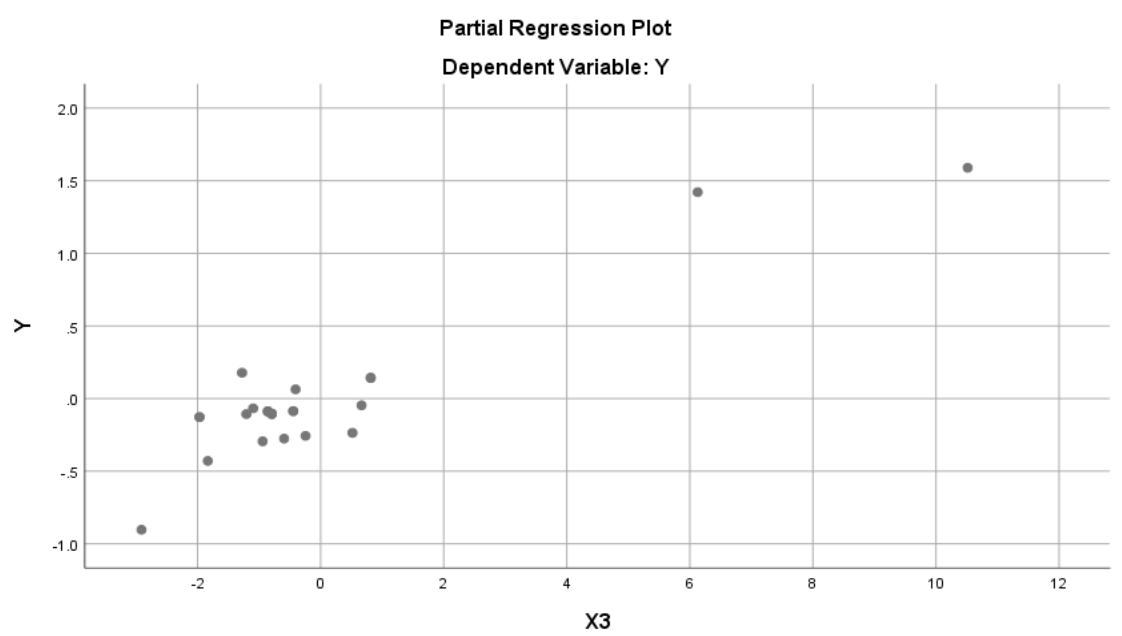

\section{Gambar 7. Data Output Uji Heteroskedastisitas Variabel Kepemimpinan Sumber: Data Primer Diolah (2019)}

Berdasarkan Gambar 7 di atas, dapat diketahui bahwa tidak terjadi heteroskedastisitas pada variabel kepemimpinan terhadap kinerja pegawai, sebab tidak ada pola yang jelas serta titiktitik menyebar di atas dan di bawah angka 0 pada sumbu $Y$ sehingga dapat dikatakan uji heteroskedastisitas terpenuhi.

Secara umum, hasil uji heterokedastisitas menunjukkan bahwa ketiga variabel independen yang di uji dalam model regresi, yaitu budaya organisasi, motivasi, dan kepemimpinan terhadap kinerja pegawai tidak menunjukkan terjadinya gejala atau penyimpangan heterokedastisitas sehingga dapat untuk dilakukan analisis regresi.

Analisis Deskriptif

Statistik deskriptif memberikan informasi secara deskriptif dari variabel-variabel independen dan dependen secara statistik dalam penelitian ini. Berikut ini adalah hasil uji statistik deskriptif untuk variabel penelitian yaitu variable budaya organisasi, motivasi, kepemimpinan dan kinerja pegawai yang ditampilkan seperti terlihat pada Tabel 3.

Tabel 3.

Analisis Deskriptif Variabel Penelitian

\begin{tabular}{|c|c|c|c|c|c|}
\hline & $\mathrm{N}$ & Minimum & Maximum & Mean & Std. Deviation \\
\hline Budaya_Organisasi & 24 & 45 & 90 & 69.46 & 13.667 \\
\hline Motivasi & 24 & 25 & 50 & 38.87 & 7.804 \\
\hline Kepemimpinan & 24 & 22 & 45 & 35.38 & 6.520 \\
\hline Kinerja_Pegawai & 24 & 20 & 40 & 31.13 & 6.017 \\
\hline Valid N (listwise) & & & & & \\
\hline
\end{tabular}

Sumber: Data Primer Diolah (2019)

Hasil uji statistik deskriptif pada Tabel 3 di atas, menunjukkan bahwa dari jumlah sampel $(\mathrm{N})$ sebanyak 24, diketahui bahwa rata-rata (mean) persepsi responden menilai budaya organisasi adalah sebesar 3,96 atau termasuk dalam kategori baik. Hal ini mengindikasikan bahwa budaya organisasi yang dapat dilihat dari delapan belas indikator termasuk dalam kategori baik.

Rata-rata (mean) persepsi responden menilai motivasi adalah sebesar 3,97 atau termasuk dalam kategori baik. Hal ini mengindikasikan bahwa motivasi yang dapat dilihat dari sepuluh indikator termasuk dalam kategori baik.

Rata-rata (mean) persepsi responden menilai kepemimpinan adalah sebesar 3,93 atau termasuk dalam kategori baik. $\mathrm{Hal}$ ini mengindikasikan bahwa kepemimpinan dapat dilihat dari sembilan indikator termasuk dalam kategori baik. Sedangkan Rata-rata (mean) persepsi responden menilai kinerja pegawai adalah sebesar 3,95 atau termasuk dalam kategori baik. Hal ini mengindikasikan bahwa kinerja pegawai dapat dilihat dari delapan indikator termasuk dalam kategori baik.

\section{Uji Goodness of fit}

Uji $F$ atau uji koefisien regresi secara bersama-sama digunakan untuk mengetahui apakah secara bersama-sama variabel independen berpengaruh signifikan terhadap variabel dependen. Dalam penelitian ini Uji $F$ dilakukan untuk 
mengetahui pengaruh variabel budaya organisasi, motivasi, dan kepemimpinan secara bersama-sama terhadap kinerja pegawai. Dari hasil uji ANOVA untuk uji secara simultan diketahui nilai signifikansi adalah 0,000 dengan nilai $F$ hitung 6293,288 dan nilai $F$ tabel 2,74 . Dengan taraf $F$ hitung $(6293,288)$ $>$ nilai $F$ tabel $(2,74)$, maka memberikan informasi bahwa terdapat pengaruh yang positif dan signifikan antara variabel budaya organisasi, motivasi, dan kepemimpinan secara bersama-sama terhadap kinerja pegawai. Hal ini menandakan bahwa apabila ketiga variabel independen secara bersama-sama digabung, maka dapat berdampak bagi peningkatan kinerja pegawai.

\section{Uji Determinasi (R Square)}

Uji determinasi dalam regresi berganda digunakan untuk mengetahui persentase sumbangan yang diberikan oleh masing-masing variabel independen secara simultan kepada variabel dependen. Dalam penelitian ini, nilai koefisien determinasi digunakan untuk mengetahui sumbangan pengaruh dari variabel budaya organisasi, motivasi, dan kepemimpinan secara bersama-sama terhadap kinerja pegawai. Dengan nilai rentang yang mendekati I menunjukkan bahwa koefisien determinasi dari model regresi yang di teliti mempunyai pengaruh yang semakin kuat terhadap model penelitian. Berdasarkan hasil analisis diperoleh nilai koefisien determinasi yaitu sebesar 0,988 atau sebesar $\mathbf{9 8 , 8 4 \%}$. Hasil analisis tersebut menunjukkan bahwa sumbangan pengaruh variabel budaya organisasi, motivasi, dan kepemimpinan yang digunakan dalam model penelitian dapat merepresentasikan variasi variabel kinerja pegawai sebesar $98,8 \%$, sedangkan sisanya sebesar 1,2\% dipengaruhi oleh model lain yang tidak di teliti atau di luar penelitian.

\section{Uji Hipotesis}

Uji t atau uji koefisien regresi secara parsial digunakan untuk mengetahui apakah secara parsial variabel independen berpengaruh secara signifikan atau tidaknya terhadap variabel dependen. Uji parsial diketahui dengan melihat hasil output SPSS dari nilai $t$ hitung masing-masing variabel independen dengan membandingkan dengan nilai $t$ tabel. Hasil analisis secara parsial yang terdiri dari variabel budaya organisasi $\left(X_{1}\right)$ memiliki nilai $t$ hitung sebesar 2,800 yang lebih besar dari nilai $t$ tabel yaitu 2,539 dengan signifkansi sebesar 0,01I < taraf signifikansi 0,05 . Artinya variabel budaya organisasi memiliki pengaruh yang signifikan terhadap kinerja pegawai sehingga hipotesis pertama $\left(H_{1}\right)$ diterima. Demikian juga dengan nilai t hitung dari variabel motivasi $\left(\mathrm{X}_{2}\right)$ adalah 7,256 > dibandingkan nilai $t$ tabel yaitu 2,539 dengan taraf signifkansi sebesar 0,000 yang lebih kecil dari signifikansi 0,05 . Hal tersebut menunjukkan bahwa variabel motivasi memiliki pengaruh yang signifikan terhadap kinerja pegawai sehingga hipotesis kedua $\left(\mathrm{H}_{2}\right)$ diterima. Kemudian dengan nilai $t$ hitung dari variabel kepemimpinan $\left(X_{3}\right)$ adalah $10,801>$ dibandingkan nilai $t$ tabel yaitu 2,539 dengan taraf signifkansi sebesar 0,000 yang lebih kecil dari signifikansi 0,05 . Hal tersebut menunjukkan bahwa variabel kepemimpinan memiliki pengaruh yang signifikan terhadap kinerja pegawai sehingga hipotesis ketiga $\left(\mathrm{H}_{3}\right)$ diterima.

\section{Pembahasan}

Pengaruh Budaya Organisasi Terhadap Kinerja
Pegawai

Hasil analisis menunjukkan bahwa budaya organisasi berpengaruh positif dan signifikan terhadap kinerja pegawai. Hasil pengujian hipotesis ini juga menjelaskan bahwa semakin baik pemahaman budaya organisasi dari seluruh pegawai, maka semakin baik pula kinerja pegawai pada Dinas Komunikasi dan Informatika Kabupaten Kotawaringin Timur. Rata-rata (mean) persepsi responden menilai budaya organisasi adalah sebesar 4,12 atau termasuk dalam kategori baik. Dengan rata-rata (mean) tertinggi (maximum) sebesar 4,08 dan terendah sebesar 3,67. Secara umum, hal ini mengindikasikan bahwa tingkat budaya organisasi yang di nilai melalui delapan belas indikator dalam mewujudkan tujuan organisasi termasuk dalam kategori baik.

Untuk meningkatkan budaya organisasi, perlu meningkatkan pemahaman akan budaya organisasi bagi para pegawai terutama mengenai penjelasan secara detail terhadap tugas yang dibagikan dan peningkatan kerjasama tim dalam menyelesaikan pekerjaan kantor. Dalam penerapannya, pimpinan dapat melakukan evaluasi terhadap penyelesaiaan tugas-tugas yang diberikan kepada para pegawai sesuai dengan waktu yang telah ditentukan serta pemahaman tentang pentingnya kerjasama tim dalam menyelesaikan pekerjaan sehingga dapat meningkatkan kinerja pegawai maupun organisasi.

Budaya organisasi memiliki pengaruh yang signifikan terhadap kinerja suatu organisasi hal ini sesuai dengan hasil penelitian terdahulu yang dilakukan antara lain oleh Amanda, dkk (2017) yang menyimpulkan bahwa budaya organisasi 
berpengaruh signifikan terhadap kinerja. Kemudian penelitian Novziransyah (2017) menyimpulkan bahwa secara parsial budaya organisasi berpengaruh signifikan terhadap kinerja pegawai. Demikian juga dengan hasil penelitian Sagita, dkk (2018) yang menyimpulkan bahwa budaya organisasi secara parsial berpengaruh signifikan terhadap kinerja.

\section{Pengaruh Motivasi Terhadap Kinerja Pegawai}

Hasil analisis menunjukkan bahwa motivasi berpengaruh positif dan signifikan terhadap kinerja pegawai. Hasil pengujian hipotesis ini juga menjelaskan bahwa semakin baik motivasi kerja pegawai, maka semakin baik pula kinerja pegawai. Rata-rata (mean) persepsi responden menilai motivasi adalah sebesar 4,08 atau termasuk dalam kategori baik. Dengan rata-rata (mean) tertinggi (maximum) sebesar 4,08 dan terendah (minimum) sebesar 3,67 yang di nilai melalui sepuluh indikator dalam mewujudkan tujuan organisasi termasuk dalam kategori baik.

Untuk meningkatkan motivasi kerja, perlu melakukan evaluasi terhadap hasil pekerjaan yang dijadikan sebagai rujukan pegawai dalam bekerja dan keinginan atau motivasi yang belum optimal dari para pegawai terutama atas tugas yang diberikan, apakah dapat diselesaikan tepat waktu atau tidak. Dalam penerapannya, motivasi kerja yang tinggi berdampak terhadap peningkatan kinerja individu maupun organisasi.

Motivasi memiliki pengaruh yang signifikan terhadap kinerja suatu organisasi hal ini sesuai dengan hasil penelitian terdahulu yang dilakukan antara lain oleh Setiawan (20I5) yang menyimpulkan bahwa motivasi kerja berpengaruh signifikan terhadap kinerja. Kemudian penelitian Meidizar dan Rustono (2016) menyimpulkan bahwa secara parsial motivasi berpengaruh signifikan terhadap kinerja pegawai. Demikian juga dengan hasil penelitian Rahsel (2016) yang menyimpulkan bahwa budaya organisasi secara parsial berpengaruh signifikan terhadap kinerja. Hasil tersebut menunjukkan bahwa motivasi mempengaruhi kinerja pegawai dalam organisasi, dimana setiap karyawan yang memiliki motivasi kerja yang tinggi bisa dipastikan pegawai tersebut memiliki tingkat kinerja yang tinggi sehingga dapat diberikan untuk pengajuan pada hipotesis untuk penelitian ini.

\section{Pengaruh Kepemimpinan Terhadap Kinerja Pegawai}

Hasil analisis menunjukkan bahwa kepemimpinan berpengaruh positif dan signifikan terhadap kinerja pegawai. Hasil pengujian hipotesis ini juga menjelaskan bahwa semakin efektif kepemimpinan yang dilakukan dalam organisasi, maka semakin baik pula kinerja pegawai pada Dinas Komunikasi dan Informatika Kabupaten Kotawaringin Timur. Rata-rata (mean) persepsi responden menilai kepemimpinan adalah sebesar 3,93 atau termasuk dalam kategori baik. Dengan rata-rata (mean) tertinggi (maximum) sebesar 4,08 dan terendah (minimum) sebesar 3,67. Secara umum, hal ini mengindikasikan bahwa tingkat kepemimpinan yang di nilai melalui sembilan indikator dalam mewujudkan tujuan organisasi termasuk dalam kategori baik.

Untuk meningkatkan kepemimpinan, perlu melakukan peningkatan kemampuan naluriah dan membagikan notulen hasil rapat kepada para pegawai agar mengetahui setiap hasil rapat internal kantor dan melakukan evaluasi secara berkelanjutan sehingga dapat meningkatkan kinerja pegawai maupun organisasi ke depannya.

Kepemimpinan memiliki pengaruh yang signifikan terhadap kinerja suatu organisasi hal ini sesuai dengan hasil penelitian terdahulu yang dilakukan antara lain oleh Rego, dkk (2017) yang menyimpulkan bahwa kepemimpinan berpengaruh signifikan terhadap kinerja. Kemudian penelitian oleh Widiastuti (2017) menyimpulkan bahwa secara parsial kepemimpinan berpengaruh signifikan terhadap kinerja pegawai. Demikian juga dengan hasil penelitian Fazira dan Mirani (2019) yang menyimpulkan bahwa kepemimpinan secara parsial berpengaruh signifikan terhadap kinerja.

Pengaruh Budaya Organisasi, Motivasi dan Kepemimpinan Secara Simultan Terhadap Kinerja Pegawai

Hasil analisis menunjukkan bahwa budaya organisasi, motivasi, dan kepemimpinan secara bersama-sama berpengaruh positif dan signifikan terhadap kinerja pegawai. Hasil pengujian hipotesis ini juga menjelaskan bahwa semakin kuat pemahaman budaya organisasi, motivasi kerja yang baik, dan kepemimpinan yang efektif dalam organisasi, maka semakin baik pula kinerja pegawai. Sumbangan pengaruh variabel budaya organisasi, motivasi, dan kepemimpinan terhadap kinerja pegawai adalah sebesar 0,988 atau 98,8\%. Artinya kinerja pegawai yang tinggi dipengaruhi oleh adanya keberadaan variabel budaya organisasi, motivasi dan kepemimpinan sebesar 98,8\%, sedangkan sisanya sebesar I,2\% dipengaruhi oleh variabel lain di luar penelitian. Adapun variabel yang mempunyai sumbangan terbesar terhadap kinerja pegawai adalah variabel motivasi dengan nilai koefisien regresi sebesar 0,46I, kemudian diikuti oleh variabel kepemimpinan sebesar 0,169 dan yang terakhir adalah vairabel budaya organisasi 
sebesar 0,103 .

Rata-rata (mean) persepsi responden menilai kinerja pegawai pada Dinas Komunikasi dan Informatika Kabupaten Kotawaringin Timur adalah sebesar 3,95 atau termasuk dalam kategori baik. Dengan rata-rata (mean) tertinggi (maximum) sebesar 4,08 dan terendah (minimum) sebesar 3,67. Secara umum, hal ini mengindikasikan bahwa tingkat kinerja pegawai yang di nilai melalui delapan indikator dalam mewujudkan tujuan organisasi termasuk dalam kategori baik.

Hasil penelitian ini juga sejalan dengan hasil penelitian terdahulu tentang pengaruh budaya organisasi, motivasi dan kepemimpinan terhadap kinerja pegawai yang dilakukan oleh Marimin (20II), Tapoona (20I4), Shati dan Dewi (20I4), Mappamiring (2015), Brury (2016), Lingga dan Siregar (20I6), Wijayanti (20I6), Widodo (20I7), Tewal, dkk (2017), Rahayuningsih (2018) menyimpulkan bahwa budaya organisasi, motivasi dan kepemimpinan secara simultan berpengaruh positif dan signifikan terhadap kinerja pegawai.

\section{Kesimpulan}

Berdasarkan hasil penelitian dapat disimpulkan bahwa secara parsial, variabel budaya organisasi, motivasi dan kepemimpinan berpengaruh positif dan signifikan terhadap peningkatan kinerja pegawai pada Dinas Komunikasi dan Informatika Kabupaten Kotawaringin Timur. Demikian juga secara simultan, variabel budaya organisasi, motivasi dan kepemimpinan berpengaruh positif dan signifikan terhadap peningkatan kinerja pegawai.

\section{Daftar Pustaka}

Amanda, E.A., Budiwibowo, S., Amah, N. (2017). Pengaruh Budaya Organisasi Terhadap Kinerja Karyawan Di PDAM Tirta Taman Sari Kota Madiun. Assets (Jurnal Akuntansi Dan Pendidikan), Vol 6 No I, April 2017, Hal. 85-92.

Brury, Monce. (20I6). Pengaruh Kepemimpinan, Budaya Organisasi, Motivasi Kerja dan Kepuasan Kerja terhadap Kinerja Pegawai pada Kantor SAR Sorong, Jurnal Riset Bisnis dan Manajemen, Vol 04, No. 0I, I-I6.

Fazira, Y., Mirani, R. (2019). Pengaruh Kepemimpinan Terhadap Kinerja Pegawai Pada Dinas Perpustakaan Dan Kearsipan Kota Dumai. JMKSP Jurnal Manajemen, Kepemimpinan, dan Supervisi
Pendidikan), Volume 4, No. I, JanuariJuni 2019, Hal. 76-83.

Ghozali, I. (2006). Aplikasi Analisis Multivariate dengan Program SPSS. Edisi. Kedua. Yogyakarta: Penerbit Universitas Diponegoro

Gunawan, I. (20I7). Pengantar Statistika Inferensial. Cetakan ke-2. Jakarta: Rajawali Pers.

Mangkunegara, AA. Anwar Prabu. (2005), Evaluasi Kinerja SDM. Bandung: Refika Aditama.

Meidizar, G., Rustono, A. (20/6). Pengaruh Motivasi Terhadap Kinerja Karyawan (Studi Kasus Pada Pt.Primarindo Asia Infrastructure, Tbk). e-Proceeding of Management, Vol.3, No.2 Agustus 2016, Hal. I032-1040.

Novziransyah, Nanda. (2017). Pengaruh Budaya Organisasi Terhadap Kinerja Karyawan PT. PLN (Persero) Kantor Wilayah Sumatera Utara Medan. Jurnal JUMANTIK, Volume 2 Nomor I, Mei 2017, Hal, I3-25.

Rêgo, E.B., Supartha, W.G., Yasa, N.N.K. (2017). Pengaruh Kepemimpinan Terhadap Motivasi dan Kinerja Karyawan pada Direktorat Jendral Administrasi dan Keuangan, Kementerian Estatal Timor Leste. E-Jurnal Ekonomi dan Bisnis Universitas Udayana, Vol 6, No. II, Hal. 373 I-3764.

Robbins, Stephen P dan Judge, Timothy A. (2007). Perilaku Organisasi. Jakarta: Salemba Empat.

Sagita, A.A., Susilo, H., Cahyo W.S., M. (2018). Pengaruh Budaya Organisasi Terhadap Kinerja Karyawan Dengan Motivasi Kerja Sebagai Variabel Mediator (Studi Pada Pt Astra Internasional, Tbk-Toyota Auto2000 Cabang Sutoyo Malang). Jurnal Administrasi Bisnis (JAB),|Vol. 57 No.I, April 2018, Hal. 73-82.

Setiawan, Kiki Cahaya. (20I5). Pengaruh Motivasi Kerja Terhadap Kinerja Karyawan Level Pelaksana Di Divisi Operasi PT. Pusri Palembang. PSIKIS-Jurnal Psikologi Islami, Vol. I No. 2, Hal. 43-53.

Tatulus, A. D., Mandey, J., Rares, J. (20/5). Pengaruh Kepemimpinan Terhadap Kinerja Pegawai Negeri Sipil Di Kantor Kecamatan Tagulandang Kabupaten Sitaro. Jurnal Administrasi Publik, Vol.3, No.2, Hal. I-I I. 
Widiastuti, Ika. (20I7). Pengaruh Kepemimpinan Terhadap Kinerja Pegawai Di Dinas Pendidikan Kota Bandung. Jurnal Ilmiah WIDYA, Volume 4 Nomor 2 AgustusDesember 2017, Hal. 28I-286.
Yoeyong Rahsel. (20I6). Pengaruh Motivasi Kerja Terhadap Kinerja Pegawai Administrasi Pusat Universitas Padjadjaran Bandung (Studi Pada Bagian Administrasi Umum UNPAD). Jurnal Manajemen Magister, Vol. 02. No. 02, Juli 2016, Hal. 208-220. 